\title{
TNF-inhibitor drugs regulate human pathogenic Th17 cells through induction of IL-10
}

\author{
Hayley G Evans ${ }^{1 *}$, Nicola J Gullick², Gina J Walter ${ }^{1}$, Urmas Roostalu', Klaus S Frederiksen³, Jens G Gerwien², \\ Andrew P Cope ${ }^{1,4}$, Frederic Geissmann ${ }^{1}$, Bruce W Kirkham ${ }^{4}$, Leonie S Taams ${ }^{1}$ \\ From 7th European Workshop on Immune-Mediated Inflammatory Diseases \\ Noordwijk aan Zee, the Netherlands. 28-30 November 2012
}

\section{Background}

TNF- $\alpha$ inhibitor (TNFi) therapy has revolutionized the treatment of immune-mediated inflammatory diseases, including rheumatoid arthritis (RA). IL-17-producing CD4 + T-cells (Th17 cells) are considered important contributors to the pathogenesis of RA. Here we investigated the effects of TNFi drugs on the function and plasticity of human Th17 cells.

\section{Methods}

The frequency of cytokine-expressing cells was assessed by flow cytometry. For functional studies, CD4+ T-cells and autologous CD14+ monocytes were co-cultured with anti-CD3 $\mathrm{mAb}$ in the absence or presence of different TNFi drugs. Cytokine secretion assays were used to resort cytokine-producing CD4+ T-cells.

\section{Results}

Ex vivo analysis of patients with RA on TNFi therapy revealed an enrichment of Th17 cells in peripheral blood compared to those on disease-modifying anti-rheumatic drugs or healthy controls. However, we also found an increase in IL-10-producing CD4+ T-cells. The enrichment in IL-17+ and IL-10+ CD4+ T-cells, including IL17+IL-10+ co-expressing CD4+ T-cells, was recapitulated in vitro by the addition of TNFi drugs (adalimumab, infliximab, etanercept, and certolizumab) to human monocyte/CD4+ T-cell co-cultures. IL-10 induction was independent of Fc $\gamma \mathrm{R}$ binding, IL-10 and CD4+CD25+ Tregs. TNFi-induced Th17 cells were functionally distinct as shown by an ability to modulate CD14+ monocytes in an IL-10-dependent manner. We report the identification of a transcription factor that is strongly

${ }^{1}$ Centre for Molecular \& Cellular Biology of Inflammation (CMCBI), King's College London, UK

Full list of author information is available at the end of the article associated with IL-10 expression in TNFi-induced IL-17+ CD4+ T-cells, and show that overexpression of this transcription factor drives IL-10 expression in primary CD4+ T-cells.

\section{Conclusions}

TNFi drugs may exert their anti-inflammatory role, at least in part, by promoting Th17 plasticity through the induction of IL-10 expression in pathogenic Th17 cells.

\section{Author details}

'Centre for Molecular \& Cellular Biology of Inflammation (CMCBI), King's College London, UK. ²Dept Rheumatology, King's College Hospital, London, UK. ${ }^{3}$ Novo Nordisk A/S, Biopharmaceuticals Research Unit, Inflammation Biology, Måløv, Denmark. `Dept Rheumatology, Guy's \& St Thomas' NHS Foundation Trust, London, UK.

Published: 28 November 2012

doi:10.1186/1479-5876-10-S3-P49

Cite this article as: Evans et al:: TNF-inhibitor drugs regulate human pathogenic Th17 cells through induction of IL-10. Journal of Translational Medicine 2012 10(Suppl 3):P49.

Submit your next manuscript to BioMed Central and take full advantage of:

- Convenient online submission

- Thorough peer review

- No space constraints or color figure charges

- Immediate publication on acceptance

- Inclusion in PubMed, CAS, Scopus and Google Scholar

- Research which is freely available for redistribution

\section{Biomed Central}

